\title{
Children in conflict with law in India
}

\section{Introduction}

A child is born with purity and innocence. Nurturing child is a crucial in every child's life and if given proper care and attention in right way after that child grows in constructive manner. Children show good performance when children's surrounding environment is positive and supportive towards them. Childs physical, psychological, moral and spiritual development builds them competent of become conscious to understand their capabilities. On the other side, detrimental environment, lack of basic needs, poor parenting supervision, other factors may turn a child to a delinquent i.e. a juvenile delinquent. In the India, juvenile delinquency is one of social problems affecting not only on children with conflict in law but it affects families, communities, and society. Childs criminal behavior makes family suffer.

Children represent about 38 to $40 \%$ of India's total population and India has highest children in the world. India has a National Policy for Children proclaim children to be a national asset. Yet, Indians children continue to be in difficult circumstances. According to National Crimes Records Bureau report of 2015, a rate of crime under cases of juveniles in conflict with law has been increased from 1.7 to $2.5 \%$ since 2005 to 2015 . There has been $0.8 \%$ increase in cases registered under IPC against Juveniles in conflict with the law during 2015. In 2015 cases registered against Juveniles in conflict with the law were 33,526 . In 2005, the number of cases was 18,939. (NCRB, 2015). These figures drawn the attention to focus on psychosocial issues of Children with conflict in law in India.

\section{Recent issues of crimes by children in India}

A lot of debate happened at Government, NGOs, Media and public level regarding crimes done by children under 18 years old since 2012. Few major incidents were October, 2012: A 16 year old Delhi boy killed a 4 year old boy. Dec., 2012: A 23 year old medical student is raped by six men, one of whom is juvenile. August, 2013: A 22 year old photojournalist is raped by five men at Shakti Mills in Mumbai. One of the suspects is under 18. September, 2013: A 12 year old girl is raped by five boys ${ }^{\text {ee }}$ ages between 12-16 years (The Times of India, Delhi, September 22, 2013 ) One of the six men involved in the Nirbhaya gang-rape 12 in Delhi, was a juvenile at the time of committing the crime. ${ }^{1}$

Crimes have been increasing in spite of many efforts investing from different stakeholders in order to improving education, health, economic, policy and programmes of children in India. Professional social workers need to focus on psychosocial issues of juvenile delinquency in this context.

\section{Juvenile justice act (2000)}

Section 2 (1) of the Juvenile Justice Act, $2000^{2}$ has defined-juvenile in conflict with law as a juvenile who is alleged to have committed an offence and has not completed eighteenth year of age as on the date of commission of such offence.

\section{Juvenile justice act (2015)}

i. Section 2(12) child means a person who has not completed eighteen years of age.
Volume 2 Issue 3 - 2017

\author{
SusheelkumarV Ronad,' Ashok S Kori, ${ }^{2}$ \\ Shrinivas Kosagi, ${ }^{3}$ Obanaik P, ${ }^{2}$ Prashant Patil ${ }^{2}$ \\ 'Department of Psychiatric Nursing, Dharwad Institute of \\ Mental Health and Neurosciences, India \\ ${ }^{2}$ Department of Psychiatric Social Work, Dharwad Institute of \\ Mental Health and Neurosciences, India \\ ${ }^{3}$ Department of Psychiatry, Dharwad Institute of Mental Health \\ and Neurosciences, India
}

Correspondence: Susheelkumar V Ronad, Department of Psychiatric Nursing, Dharwad Institute of Mental Health and Neurosciences, India, Email susheelronad@gmail.com

Received: November 15, 2016 | Published: February 27, 2017

ii. Section 2(13)“child in conflict with law means a child who is alleged or found to have committed an offence and who has not completed eighteen years of age on the date of commission of such offence.

iii. Section 2(21) child care institution means Children Home, open shelter, observation home, special home, place of safety, Specialized Adoption Agency and a fit facility recognized under this Act for providing care and protection to children, who are in need of such services.

iv. Section 2(35) juvenile means a child below the age of eighteen years.

\section{Causes of juvenile delinquency}

The study B. R. Sharma, Sangeet Dhillon et al. ${ }^{3}$ noted that childhood incidents and experiences are significant in the development of criminality; on the other hand, it does not mean criminals expose their criminality early in life Causes of Juvenile delinquency required to understand from sociological theories of juvenile delinquency, these theories put prominence on the environment, social structures and the learning process. Yet, many factors that take part in vital part in a youngsters delinquent behavior. ${ }^{3}$

The study by B. R Sharma, Sangeeth Dhillon et al. ${ }^{3}$ they mentioned individual factors cause for Juvenile delinquency. Individual factors are personality traits like submissiveness, defiance, hostility, impulsiveness, feeling of insecurity, fear, lack of selfcontrol and emotional conflicts whereas situational factors are family, companions, movies, school environment, work environment etc.

Commonly, children need support, love, affection, keen parenting support and involvement of family members is required to every child become healthy. When these basic needs are missing which may affect child's personality.

The study of Haveripeth $\mathrm{PD}^{4}$ describes that causes of juvenile delinquency are broken homes, lack of love, lack of parental affection, gang subculture, poverty, negative influence of movie and media, urbanization, adolescent instability, lack of recreation, negative environment, low-socio economic, poor parental violence, availability of weapons, association with deviant peers, parental substance use, 
peer pressure, television violence, parental anti social behaviour, poor academic performance, large family size, low educational attainment, drug or alcohol use of child, poor monitoring of children in school and criminal behaviour of siblings. ${ }^{4}$

One study shows that causes of Juvenile crime due to bad company, extra-pocket money, revenge factor, poor literacy rate, over exposure to media, lack of values, cheap literature, love of adventures, early sex experience and mental conflicts etc. ${ }^{1}$ Juveniles are apprehended due to many reasons. Financial problem is not a single factor for juvenile delinquency, other factors increases the likelihood of juvenile delinquency.

Children involve in crimes and soon after such children apprehended by police officers as per law in India. Police officers register cases against children who make offenses of using forged or counterfeit currency/bank notes, grievous hurt, acid attack, attempt to acid attack, assault on women with intent to outrage her modesty, sexual harassment, assault on women, importation of girls from foreign country, causing death by negligence, industrial, political, caste conflict -SC/STs Vs. Non-SCs/STs, other caste riots, agrarian, other riots, criminal breach of trust and cheating forgery, murder, attempt to commit murder, rape, dacoity, robbery, theft riots, breaking unlawful assembly, making preparation and assembly for committing, attempt to commit rape, kidnapping \&abduction, communal, deaths due to negligent driving/act, deaths due to other causes, offences against State, sedition, other offences against State, offences promoting enmity between different Groups, promoting enmity on ground of religion race and place of birth causing injuries under rash driving/ road rage, human trafficking (Section 370 \& 370A IPC), unnatural offences and Other IPC crimes cases. ${ }^{5}$

\section{Juvenile offenders}

There is no single profile or adequate characterization of the diverse group of youth who come to be identified as juvenile offenders. Most youths who commit crimes as juveniles desist in early adulthood, and most who come to juvenile court never return on a new referral. However, a small group of juveniles is prone to continued offending.

\section{Risk factors}

The study by Kazdin et al. $^{6}$ indicates that a risk factor predicts an increased probability of later offending. ${ }^{6}$ The study by Shader noted that some risk factors for juvenile delinquency at individual level in the early onset (6-11years) are general offenses, substance use being male aggression, hyperactivity problem (antisocial) behaviour, exposure to television violence, medical, physical problems, low IQ, antisocial attitudes, beliefs Dishonesty. At late onset (12-14years) are general offenses, restlessness, difficulty in concentrating, risk taking aggression, being male, physical violence, antisocial attitudes, beliefs, Crimes against persons, problem (antisocial) behaviour, low IQ and substance use. Risk factors at family level associated with juvenile delinquency. These risk factors in early onset in age group of 6-11years are low socioeconomic status/poverty antisocial parents, poor parentchild relationship, harsh, negligent, or inconsistent discipline, broken home, separation from parents. In late onset (12-14years) are poor parent-child relationship, harsh or lax discipline, poor monitoring, supervision, low parental involvement, antisocial parents, broken home, low socioeconomic status, poverty, abusive parents, and family conflict. School environment impacts on child's behaviour. Certain risk factors at school level are associated with juvenile delinquency.
Such risk factors are poor attitude poor academic failures. ${ }^{7}$ Hence identifying these risk factors at individual, family and school level gives insights for social workers before providing psychosocial interventions. And efforts to reduce risk factors could prevent making crimes by juvenile delinquents.

\section{Methodology}

The study followed web based literature survey (secondary data) using Pubmed, Ebsco, Psyinfo, Government websites, etc by using key words such as children, Juvenile Delinquency, psycho-social issues, intervention like on. The researcher found about 80 studies which discussed on various aspects of children with conflict with law. The reviewer had chosen important studies for the review purpose.

\section{Discussion and results}

It is crucial to make aware of different crimes of juveniles who involved in crimes are not criminals in many cases, in fact, they are victims of society. ${ }^{8}$ According NCRB report, ${ }^{5} 2037$ cases registered against children with conflict in law under different crimes of special and local laws during 2015, the data shows that 218 children faced legal complications due to Gambling and apprehended under Gambling Act, 1867 and it is the highest cases compare to other types of crimes in 2015 .

Children were apprehended under different acts of India in 2015, few acts were Children Arms Act, 1959, Narcotic Drugs \& Psychotropic Substances, Excise Act, 1944, Prohibition Act, Explosives \& Explosive Substances Act, 1884, Immoral Traffic (Prevention) Act, 1956, Protection of Civil Rights Act, 1955, Passport Act, 1967, Protection of Children from Sexual Offences Act 1987, SC/ST (Prevention of Atrocities), Forest Act, 1927, Prohibition of Child Marriage Act, 2006, Protection of Women From Domestic Violence Act, 2005, Information Technology Act, 2000, Official Secrets Act, 1923, Air (Prevention \& Control of Pollution) Act, 1981, Wildlife Protection Act, 1972, National Security Act, 1980, Other acts. This gives picture about different crime acts by children in India. Social work interventions at individual, family and community level shall conduct preventive programmes in order to prevent crimes of juveniles in India. Many of children do not know about consequences of committing offenses.

Good parenting enhances Childs confidence to be healthy. Marital conflict, interpersonal issues between couple, broken home, single parenting may affect Childs personality. The study conducted by Colemanet al., ${ }^{9}$ indicates that children single-parent families are about 10 to 15 percent more likely to turn into delinquent that are children with similar social characteristics from two parent families. Hence, social work implications like family therapy, counseling could alter family interaction pattern into child's favorable way.

Children's current daily activities need to administer by family members daily by explaining children about consequences of watching violence videos in Television. Social Work implications are highly required to educate the family members or parents about consequences of watching violence videos. This can be done through awareness programmes and counseling approaches.

Juvenile delinquency is associated with various factors. Bridges $\mathrm{KB}^{10}$ noted that these factors are classed under six general headings: Physical factors, mental factors, Home conditions, School conditions, Neighborhood conditions, and Occupational conditions. The first 
two groups include all factors dependent upon the bodily and mental condition of the delinquent. These are the product of both heredity and environment. The other four groups consist of environmental factors: unfavorable conditions in the home and the family of the child, unfavorable, conditions in the school environment, the neighborhood, and occupational environments.

\section{Social workers}

Social workers in correctional settings especially working in observation homes, have a variety of roles that range from direct patient care to liaison with outside agencies on behalf of their clients. Social workers direct care delivery is provided through counselling which is effective for juvenile offenders. And other therapeutic modalities such as rehabilitation model, group therapy, and such therapies are individual and group therapy, Individual psychotherapy; Person centred approach, cognitive behaviour therapy. ${ }^{11-15}$

\section{Role of nurses in caring for juvenile delinquent children and their families}

The most effective way to prevent juvenile delinquency has indisputably been to assist children and their families early on. Numerous state programs attempt early intervention, and federal funding for community initiatives has allowed independent groups to tackle the problem in new ways. ${ }^{16-19}$ The most effective programs for juvenile delinquency prevention share the following key components:

\section{Education}

Model programs have assisted families and children by providing them with information. Some programs inform parents on how to raise healthy children; some teach children about the effects of drugs, gangs, sex, and weapons; and others aim to express to youth the innate worth they and all others have. All of these programs provide youths with the awareness that their actions have consequences. This is particularly important in an era where youth are barraged with sexual and violent images. ${ }^{20-24}$ Educational programs have the underlying intent of encouraging hope and opening up opportunities for young people.

\section{Recreation}

One of the immediate benefits of recreational activities is that they fill unsupervised after-school hours. The Department of Education has reported that youths are most likely to commit crimes between 2 p.m. and 8 p.m., with crime rates peaking at 3 p.m. Recreation programs allow youths to connect with other adults and children in the community. Such positive friendships may assist children in later years. Youth programs are designed to fit the personalities and skills of different children and may include sports, dancing, music, rock climbing, drama, karate, bowling, art, and other activities..$^{25}$

\section{Community involvement}

Girl scouts, boy scouts, church youth groups, and volunteer groups all involve youth within a community. Involvement in community groups provide youth with an opportunity to interact in a safe social environment. ${ }^{26}$

\section{Prenatal and infancy home visitation by nurses}

Nurses involved in the "Prenatal and Infancy Home Visitation by Nurses" program pay visits to low income, single mothers between their third trimester and the second year of their child's life. During these visits, nurses focus on the health of the mother and child, the support relationships in the mother's life, and the enrolment of the mother and child in Health and Human Services programs. A 15year follow-up study found that mothers and children involved in the program had had a 79 percent lower child abuse rate, a 56 percent lower child runaway rate, and a 56 percent lower child arrest rate. Maternal behaviour problems also dropped significantly in the studied group. ${ }^{27}$

\section{Parent-child interaction training program}

The "Parent-Child Integration Training Program" takes parents and children approximately 12 weeks to complete. It is designed to teach parenting skills to parents of children age's two to seven who exhibit major behavioural problems. The program places parents and children in interactive situations. A therapist guides the parents, educating them on how best to respond to their child's behaviour, whether positive or negative. The program has been shown to reduce hyperactivity, attention deficit, aggression, and anxious behaviour in children. ${ }^{28}$

\section{Bullying prevention program}

The Bullying Prevention Program is put into place in elementary and junior high school settings. An anonymous student questionnaire fills teachers and administrators in as to who is doing the bullying, which kids are most frequently victimized, and where bullying occurs on campus. Once teachers and administrators have learned about how and where bullying occurs at their school, they set up class rules and facilitate discussions that address the problem. Individual bullies and victims receive independent counselling. The program succeeds in creating a safer, less hostile environment for students at minimal cost. ${ }^{29,30}$

\section{Conclusion}

From the above discussion serious crimes like rape and murders also go unpunished with the offender wearing the grab of juvenility. Juvenile crimes cannot be stopped only through the proper implementation and amendments of Juvenile Justice Act. It is important to make aware about different reasons for involving crimes by parents and guardians. Juveniles involved in crimes are not criminals; in fact, they are victims of society in some cases. Juvenile delinquency can be stopped at an early stage, provided special care is taken both at home and in school. Parents and teachers play a major role in fostering the mind of a child. Instead of labeling them as criminals or delinquents, importance to be given on understanding needs of children and give them a scope of modification. The problem of child crime like many other social problems is linked up with the imperfections and maladjustment of our society.

\section{Acknowledgements}

None.

\section{Conflict of interest}

The authors declare no conflict of interest.

\section{References}

1. Dey M. Juvenile justice in India. IJIMS. 2014;1(6):64-70.

2. Juvenile Justice Act; 2000. 
3. Sharma BS, Dhillon. Juvenile delinquency in India A cause for concern. J Indian Acad Forensic Med. 2009;31(1):68-70.

4. Haveripeth PD. Contributing factors of juvenile delinquency. International Journal of Innovative Research and Development. 2013;2(1):8-16.

5. National crime records bureau, Ministry of home affairs, Government of India Narayana KS. Dimensions of juvenile problems: institutional and non-institutional. Soc Welfare. 2005;51(10):13-25.

6. Kazdin AE, Kraemer HC, Kessler RC, et al. Contributions of riskfactor research to developmental psychopathology. Clin Psychol Rev. 1997; 17(4):375-406.

7. Shader M. Risk factors for delinquency: An overview, US Department of Justice, Office of Justice Programs, Office of Juvenile Justice and Delinquency Prevention; 2001.

8. Jain K A. Study of juvenile delinquents in India: A Burning Issue.

9. Coleman, James William, Harold Kerbo. Social Problems. 9th ed. USA: Pearson Prentice Hal; 2006.

10. Bridges KB. Factors contributing to juvenile delinquency. Journal of Criminal Law and Criminology. 1927;17(4):531-580.

11. Fatima N. Juvenile rights of individuals in mental health setup. The Rights. 2015;1(2):10.

12. Comanor WS, Phillips L. The impact of income and family structure on delinquency. Journal of Applied Economics. 2002;5(2):209-232.

13. Haveripet P. Causes and consequences of juvenile delinquency in India. Recent Research in Science and Technology. 2013;5(3):29-31.

14. Pradheepa P, Murlidharan K. Juvenile delinquency a socioeconomic and family perspective. Soc Welfare. 2005;51(10):9-12.

15. Kethineni S, Klosky T. The impact of juvenile justice reforms in India. International Journal of Offender Therapy and Comparative Criminology. 2000;44(3):312-325.

16. Bishop DM. Juvenile offenders in the adult criminal justice system. Crime and justice. 2000;27:81-167.

17. Tittle CR, Paternoster R. Social deviance and crime: An organizational and theoretical approach. Los Angeles, USA: Roxbury Publishing Company;2000.
18. Bartol AM, Bartol CR. Criminal behavior: A psychological approach. Boston, USA: Pearson; 2014.

19. Sharma R. Legal framework for children in conflict with law in india problems and prospects. Indian Journal of Social Work. 2010;71(3):351373.

20. Malhotra C, Sharma N, Saxena R, et al. Drug use among juveniles in conflict with the law. Indian J Pediatr. 2007;74(4):353-356.

21. Malhotra S, Kohli A, Kapoor M, et al. Incidence of childhood psychiatric disorders in India. Indian J Psychiatry. 2009;51(2):101-107.

22. Patel V, Flisher AJ, Nikapota A, et al. Promoting child and adolescent mental health in low and middle income countries. J Child Psychol Psychiatry. 2008;49(3):313-334.

23. Shastri PC. Promotion and prevention in child mental health. Indian $J$ Psychiatry. 2009;51(2):88-95.

24. Kakar S. Juvenile justice and juvenile delinquency in India. In The Handbook of Juvenile Delinquency and Juvenile Justice. USA: John Wiley \& Sons; 2015

25. Bhattacharya S, Bhattacharya S. Human rights violations of children in India: An overview. International Journal of Child and Adolescent Health. 2015;8(1):51-70.

26. Kumari V. Juvenile justice in India. Juvenile Justice in Global Perspective. 2015;145-197.

27. Chandrashekar SV. Offences against Children: Criminal justice and social issues in India. Suicide. 2014;56(61):144.

28. Roy A, Khetrapal P. Child abuse: a real great challenge for modern societies: the protection of children from sexual offences act, 2012 may prove to be a weapon for safeguarding the children; 2012.

29. Kaur K, Kumar S. A small survey of juvenile delinquency crime in India. International Journal of Innovative Research and Development. 2012;1(4):290-302.

30. Agarwal S, Kumar N. Juvenile Justice (Care and Protection of Children) Act 2015: A Review. Space and Culture, India. 2016;3(3):5-9. 